TITLE:

\title{
ECOLOGICAL STUDIES ON THE JELLY-FISH, AURELIA AURITA (LINNE), IN URAZOKO BAY, FUKUI PREFECTURE -XI. AN OBSERVATION ON EPHYRA FORMATION
}

\author{
$\operatorname{AUTHOR}(\mathrm{S}):$ \\ Yasuda, Toru
}

\section{CITATION:}

Yasuda, Toru. ECOLOGICAL STUDIES ON THE JELLY-FISH, AURELIA AURITA (LINNE), IN URAZOKO BAY, FUKUI PREFECTURE -XI. AN OBSERVATION ON EPHYRA FORMATION. PUBLICATIONS OF THE SETO MARINE BIOLOGICAL LABORATORY 1975, 22(1-4): 75-80

\section{ISSUE DATE:}

1975-07-31

URL:

http://hdl.handle.net/2433/175889

RIGHT: 


\title{
ECOLOGIGAL STUDIES ON THE JELLY-FISH, AURELIA AURITA (LINNÉ), IN URAZOKO BAY, FUKUI PREFEGTURE-XI. AN OBSERVATION ON EPHYRA FORMATION
}

\author{
TôRU YASUDA \\ Fukui Prefectural Fisheries Experimental Station, \\ Tsuruga, Fukui Prefecture, Japan
}

With Text-figure 1

Although many studies are noted on the asexual reproduction of Aurelia aurita polyp (e.g. Agassiz 1862, Haeckel 1881, Percival 1923, Gilchrist 1973, Verwey 1942, Berrill 1949, Hirai 1958, Kakinuma 1961, 1963, Custance 1964, 1966, 1967, Spangenberg 1965, 1967a, 1968, 1971, Thiel 1962, 1966, Chiba 1969), the direct development from fertilized eggs or planulae to single ephyrae has been reported very rarely.

So far as the writer is aware, such a case has been referred to only in a few short reports by Haeckel (1881), Berrill (1949), Hirai (1958) and Spangenberg (1967a, 1968), but seemingly no detailed studies have ever been made on this phenomenon.

In the course of ecological studies on the jelly-fish, Aurelia aurita, in Urazoko Bay, Fukui Prefecture, some laboratory experiments were carried out to see how the fertilized eggs or planulae develop to ephyrae under the natural condition. From the results obtained, the writer was able to learn the days needed to ephyra liberation and the ratio between the normal polyp formation and the direct ephyra liberation without regular polyp formation and strobilation.

In preparing this paper, the writer is grateful to Prof. T. Tokioka of the Seto Marine Biological Laboratory, Kyoto University, Prof. H. Ohmi of the Hokkaido University and Prof. Y. Sugiura of the Dokkyo University for their kindness in presenting suggestion and in reading the manuscript critically. Thanks are also due to Dr. Y. Kakinuma of the Asamushi Marine Biological Station, Tôhoku University and Dr. S. Nishimura of the Seto Marine Biological Laboratory, Kyoto University for their invaluable advices and suggestions in the course of this study.

\section{Material and Method}

In March to June, 1971 and April to June, 1973, mature medusae of 15 to $30 \mathrm{~cm}$ in bell-diameter were collected by a hand-net from Urazoko Bay, a small cove of Wakasa Bay on the Japan Sea coast (Yasuda 1971). Fertilized eggs or planulae attached to their oral-arms or sub-umbrella were gathered by using a syringe and 
immediately transferred to a small tank $(50 \mathrm{~cm} \times 30 \mathrm{~cm}$ wide and $30 \mathrm{~cm}$ deep $)$ with upper shells, $5 \mathrm{~cm}$ long $\times 5 \mathrm{~cm}$ high, of Pecten albicans laid on the bottom, or to five 3-liter beakers each containing three of the same shell. In the 1971 experiment, planulae collected from two or three medusae had been mixed before they were transferred to respective vessels, while in the 1973 experiment planulae obtained from respective medusae were transferred separately to different vessels. Counting of polyps and ephyrae was done under a microscope of lower magnification. Polyps or ephyrae were reared in natural sea water, with weak aeration, and fed with a rotifer, Brachionus plicatilis twice a day. The water temperature and chlorinity were checked every day at 14:00-15:00.

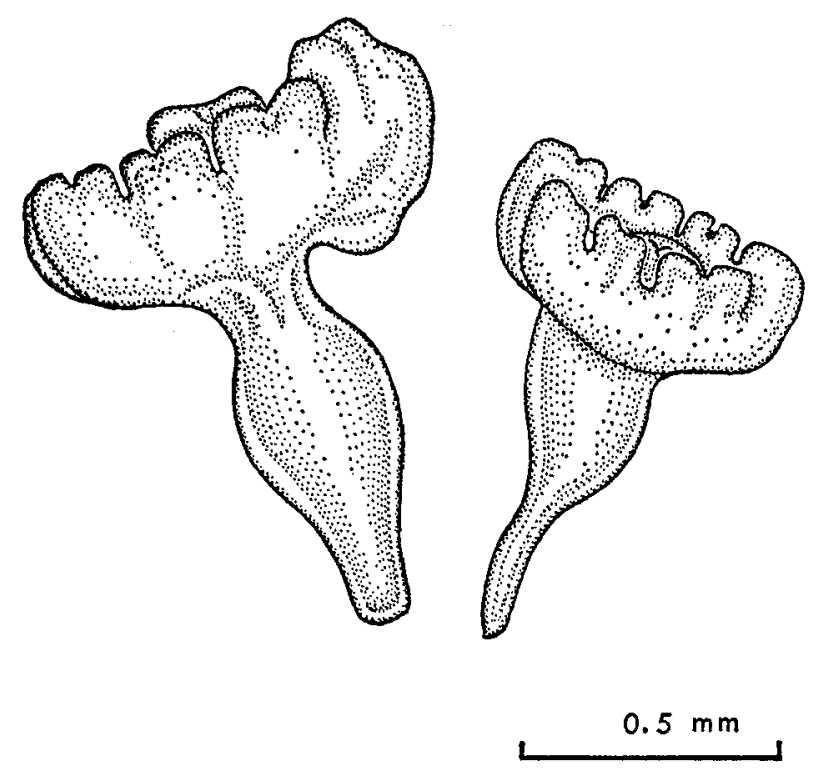

Fig. 1. Direct development from planulae to single ephyrae

\section{Results and Discussion}

Days needed to Ephyra Liberation: A stage of direct development from planulae to single ephyrae is shown in Fig. 1, and the relation between the days necessary from planula settling to ephyra liberation and the water temperature in the direct development from planulae to single ephyrae may be seen in Table 1 . The table shows that the days to the ephyra liberation are 3 to 4 days at the water temperature $20-28^{\circ} \mathrm{C}, 5$ days at $15-21^{\circ} \mathrm{C}, 7$ to 8 days at $12-15^{\circ} \mathrm{C}$, and 8 to 11 days at $6-12^{\circ} \mathrm{C}$.

Thus, evidently the higher the water temperature is, the sooner the ephyra liberation will come. The ephyra liberation in the direct development was done nearly simultaneously in a short time, so that the vessels were often filled of ephyrae liberated from the shell surface on the bottom in a few to several days after planula settling. On the other hand, the strobilation of polyps normally developed from 
Table 1. Relation between the days needed from settling to liberation and the water temperature in direct development of planula to single ephyrae.

\begin{tabular}{|c|c|c|c|c|}
\hline \multirow{2}{*}{$\begin{array}{c}\text { Date of } \\
\text { observation }\end{array}$} & \multicolumn{2}{|c|}{ Water temperature $\left(\mathrm{C}^{\circ}\right)$} & \multirow{2}{*}{$\begin{array}{c}\text { Chlorinity range } \\
(\% \circ)\end{array}$} & \multirow{2}{*}{$\begin{array}{c}\text { Days to ephyra } \\
\text { liberation }\end{array}$} \\
\hline & Range & Mean & & \\
\hline \multirow{2}{*}{ Mar. to June, 1971} & ( $6.5-12.1$ & $9.2( \pm 1.8)$ & $17.6-18.6$ & $8-11$ \\
\hline & $\{11.6-14.7$ & $13.0( \pm 1.2)$ & $18.2-18.8$ & $7-8$ \\
\hline \multirow{3}{*}{ Apr. to June, 1973} & $(15.0-21.4$ & $18.3( \pm 1.8)$ & $18.1-18.3$ & 5 \\
\hline & $\{19.8-24.6$ & $21.6( \pm 2.6)$ & $18.2-18.3$ & $3-4$ \\
\hline & $22.8-27.8$ & $24.7( \pm 2.9)$ & 17.9 & 3 \\
\hline
\end{tabular}

planulae occurred 1 month or over after planula settling at $6-27^{\circ} \mathrm{C}$. Further, it occurred sporadically, but never simultaneously at least during the writer's experiments. These observations will be reported in detail in further papers. The chlorinity ranged from 17.6 to $18.8 \%$ during the experiments, but maintained steadily nearly $18 \%$ except in the case of rearing at 6 to $12{ }^{\circ} \mathrm{C}$.

Number and Ratio of Polyps and Ephyrae developed from Planulae obtained from the Same Single Medusae: Planulae liberated from mature medusae and attached to the shell surface developed soon to regular polyps or directly to ephyrae. Number of polyps and ephyrae in respective beakers are given in Table 2 . In the pursuit of planulae from 15 to $26 \mathrm{~cm}$ medusae obtained in April, ephyrae developed directly from planulae predominated over polyps, the percentage of ephyrae to the total of polyps and ephyrae was 65.4 to $88.3 \%$ with the mean of $76.1 \%$. The same tendency is again confirmed in the next observation of the planulae obtained from medusae 20 to $30 \mathrm{~cm}$ in belldiameter in May except only the material from a $20 \mathrm{~cm}$ medusa. The percentage of ephyrae ranged from 48.1 to $68.2 \%$, with the mean of $62.7 \%$. The last observation was made on planulae from medusae of $15-20 \mathrm{~cm}$ in bell-diameter which were collected in late June when it was rather difficult to obtain mature medusae. This time, the number of polyps predominated over that of ephyrae in the two cases of 19 and $15 \mathrm{~cm}$ medusae, though in three other caces ephyrae were more numerous than polyps. The percentage of ephyrae ranged from 36.0 to $75.0 \%$ and with the mean of $57.4 \%$.

The writer has already suggested in his previous paper (Yasuda 1971) about the spawning season of Aurelia in this region by checking the existence of fertilized eggs or planulae on the oral-arms or sub-umbrella in a year from April 1969 to April 1970. And it was confirmed that the spawning season extended from January to June, in the water temperature range of $8-19^{\circ} \mathrm{G}$, and with the peak in January to May in the temperature range of $8-18^{\circ} \mathrm{G}$. Kon and Honma (1972) have reached the same conclusion by histological examination of the gonad of this medusa. On the other hand, the writer showed, on monthly sampling by a plankton-net in a year-round study from November 1966 to October 1967, that the occurrence of Aurelia ephyrae continued from middle January to late June in the water temperature range of $8-22^{\circ} \mathrm{C}$, with the peak in April in the temperature range of $11-14^{\circ} \mathrm{C}$ (Yasuda 1968). Further, it was mentioned that ephyrae were collected in Nyu-ura Bay in early February to late 
Table 2. Number and percent of polyps and ephyrae developed from the planulae obtained from the same single medusae.

a) Observation made four days after planula settling on April 11, 1973

\begin{tabular}{cccc}
\hline $\begin{array}{c}\text { Bell-diameter } \\
\text { of parent medusae }\end{array}$ & $\begin{array}{c}\text { Number of planulae } \\
\text { studied }\end{array}$ & $\begin{array}{c}\text { Developed to } \\
\text { polyps }(\%)\end{array}$ & $\begin{array}{c}\text { Developed directly } \\
\text { to ephyrae }(\%)\end{array}$ \\
\hline $15 \mathrm{~cm}$ & 301 & $104(34.6)$ & $197(65.4)$ \\
$18 \mathrm{~cm}$ & 315 & $72(22.9)$ & $243(77.1)$ \\
$22 \mathrm{~cm}$ & 175 & $54(30.9)$ & $121(69.1)$ \\
$24 \mathrm{~cm}$ & 484 & $149(30.8)$ & $335(69.2)$ \\
$26 \mathrm{~cm}$ & 606 & $71(11.7)$ & $535(88.3)$ \\
\hline
\end{tabular}

b) Observation made three days after planula settling on May 15, 1973

\begin{tabular}{cccc}
\hline $\begin{array}{c}\text { Bell-diameter } \\
\text { of parent medusae }\end{array}$ & $\begin{array}{c}\text { Number of planulae } \\
\text { studied }\end{array}$ & $\begin{array}{c}\text { Developed to } \\
\text { polyps }(\%)\end{array}$ & $\begin{array}{c}\text { Developed directly } \\
\text { to ephyrae }(\%)\end{array}$ \\
\hline $20 \mathrm{~cm}$ & 54 & $28(51.9)$ & $26(48.1)$ \\
$21 \mathrm{~cm}$ & 35 & $15(42.9)$ & $20(57.1)$ \\
$23 \mathrm{~cm}$ & 85 & $27(31.8)$ & $58(68.2)$ \\
$23 \mathrm{~cm}$ & 191 & $69(36.1)$ & $122(63.9)$ \\
$30 \mathrm{~cm}$ & 40 & $12(30.0)$ & $28(70.0)$ \\
\hline
\end{tabular}

c) Observation made two days after planula settling on June 25, 1973

\begin{tabular}{cccc}
\hline $\begin{array}{c}\text { Bell-diameter } \\
\text { of parent medusae }\end{array}$ & $\begin{array}{c}\text { Number of planulae } \\
\text { studied }\end{array}$ & $\begin{array}{c}\text { Developed to } \\
\text { polyps (\%) }\end{array}$ & $\begin{array}{c}\text { Developed directly } \\
\text { to ephyrae (\%) }\end{array}$ \\
\hline $15 \mathrm{~cm}$ & 34 & $18(52.9)$ & $16(47.1)$ \\
$18 \mathrm{~cm}$ & 72 & $18(25.0)$ & $54(75.0)$ \\
$19 \mathrm{~cm}$ & 50 & $32(64.0)$ & $18(36.0)$ \\
$20 \mathrm{~cm}$ & 26 & $8(30.8)$ & $18(69.2)$ \\
$20 \mathrm{~cm}$ & 36 & $17(47.2)$ & $19(52.9)$ \\
\hline
\end{tabular}

June in 1965-1966 (Yasuda 1969). The writer's unpublished data includes the record that the appearance of ephyrae in this region was not yet confirmed on January 20, but recognized on February 12 in 1970. In short, the spawning of Aurelia and the occurrence of ephyrae are seen nearly in the same season or the latter will surely be seen within a month after beginning of the former.

The development of the egg of Aurelia, the stages from planula to strobila and the release of ephyrae were reported as follows. In Japanese waters, Hirai (1958) reported that it needed 3.3 months after planula settling in the laboratory experiment to see the ephyra release by strobilation at Asamushi in northern Honshu.

In northern waters of Europe, Thiel (1962) made a detailed field observation in Kiel Bay and found that the stages from planula settling to ephyra release by strobilation extended over 4 months. If such a long developmental period were required in Urazoko Bay, too, the appearance of ephyrae would be seen three or four months after the beginning of the spawning season. There, however, ephyrae appear actually just after the setout of spawning. As seen in Tables 1 and 2, most of the planulae obtained 
around the peak of the spawning season in this region develop directly into ephyrae and the ephyra liberation is done explosively within eleven days after planula settling even at the water temperature below $10^{\circ} \mathrm{C}$.

On the contrary, the strobilation is found sporadically over a month after planula settling. From these facts, it may be concluded that most ephyrae collected in Urazoko Bay are probably produced by the process of direct development from planula, and that the production of ephyrae by the popular formal process from planula settling through strobilation is only supplementary in this region.

According to the laboratory observation made by Spangenberg (1967a, 1968), small starved polyps usually produced only one ephyra. In the present experiment, however, polyps were fed with dense Brachionus plicatilis. Also in the natural environments, rich zooplankters such as copepods (Paracalanus, Acartia) and cladocerans (Penilia, Evadne) were densely found in this region throughout the spawning season of Aurelia and the occurring months of ephyrae (Yasuda 1969).

Therefore, the prevalence of the direct development of planulae to ephyrae in this region can not be considered to be caused by shortened nutrition. The mature eggs of Aurelia aurita in Urazoko Bay are $0.26-0.30 \mathrm{~mm}$ in diameter (Kon and Honma 1972) and this seems a little larger than in the European forms. The prevalence of the direct development might be related to the larger egg size as suggested by Berrill $(1949)^{1)}$.

\section{Summary}

In March to June, 1971 and 1973, fertilized eggs or planulae obtained from mature medusae of Aurelia aurita collected from Urazoko Bay on the Japan Sea coast were reared experimentally in natural sea water by feeding them with a rotifer, Brachionus plicatilis. Larger parts of the planulae developed directly into ephyrae, and the ephyra liberation occurred explosively 3 to 11 days after the planula settling. Evidently, the higher the water temperature is, the sooner the ephyra liberation will come. The ephyra production by regular strobilation seems to be only supplementary in Urazoko Bay.

\section{REFERENCES}

Agassiz, L. 1862. Contribution to the natural history of the United States of America. vol. 4, pp. 1-180, $10 \mathrm{pls}$, Boston.

Berrill, N.J. 1949. Development analysis of Scyphomedusae. Biol. Rev., vol, 24, pp. 393-410.

Chiba, Y. 1969. Ecological factors affecting the strobilation of Aurelia aurita (Coelenterata: Scyphomedusa). Bull. Mar. Biol. Stat., Asamushi, vol. 13, nos. 3/4, pp. 173-178.

Custance, D.R.N. 1964. Light as an inhibitor of strobilation in Aurelia aurita. Nature, no. 204, pp. $1219-1220$.

1966. The effect of a sudden rise in temperature on strobilae of Aurelia aurita. Experientia,

1) According to Berrill (1949), the egg size of Aurelia aurita is very variable, ranging from 0.15 to $0.23 \mathrm{~mm}$ in diameter, and the largest planulae develop directly into ephyrae. 
no. 22 , pp. $1-4$.

1967. Studies on strobilation in the Scyphozoa. Jour. Biol. Educ. no. 1, pp. 79-81.

Gilchrist, F.G. 1937. Budding and locomotion in the scyphistomas of Aurelia. Biol. Bull. Mar. Biol. Lab., Woods Hole, vol. 72, pp. 99-124.

Haeckel, E. 1881. Metagenesis und Hypogenesis von Aurelia aurita. p. 36, Wien.*

Hirai, E. 1958. On the developmental cycles of Aurelia aurita and Dactylometra pacifica. Bull. Mar. Biol. Stat., Asamushi, vol. 9, no. 2, p. 81.

Kakinuma, Y. 1961. Investigation on the life cycles of some Hydrozoans and Scyphozoans from near Asamushi. Aomori Pref. Biol. Soc., vol. 4, nos. 1/2, pp. 10-17 (in Japanese).

1963. On some factors for the differentiation of Cladonema uchidai and of Aurelia aurita. Bull. Mar. Biol. Stat., Asamushi, vol. 11, no. 3, pp. 81-85.

Kon, T. and Honma, Y. 1972. Studies on gonad maturity in some marine invertebrates-V. Seasonal change in the gonad of the moon jelly. Bull. Jap. Soc. Sci. Fish., vol. 38, no. 6, pp. 545-553.

Percival, E. 1923. On the strobilization of Aurelia. Quart. J. Micr. Sci. vol. 67, no. 265, pp. 85-100.*

Spangenberg, D.B. 1965. A study of strobilation in Aurelia aurita under controlled conditions J. Exp. Zool. vol. 160, pp. 1-9.

1967a. Iodine induction of metamorphosis in Aurelia. ibid., vol. 165, pp. 441-450.

1968. Recent studies of strobilation in jelly fish. Oceanogr. Mar. Biol. Ann. Rev., vol. 6, pp. 231-247.

1971. Thyroxine induced metamorphosis in Aurelia. J. Exp. Zool. vol. 178, pp. 183-194.

Thiel, H. 1962. Untersuchungen über die Strobilisation von Aurelia aurita Lam. an einer Population der Kieler Forde. Kieler Meeresforsch. vol. 18, pp. 198-230.

1966. The evolution of Scyphozoa. A review. In W.J. Rees (ed.). The cnidaria and their evolution. (Symposia of Zoological Society of London. no. 16). pp. 77-117, London.

Verwey, J. 1942. Die Periodizität in Auftreten und die aktiven und passiven Bewegungen der Quallen. Arch. Néerland. Zool. vol. 6, no. 4. pp. 303-468.

Yasuda, T. 1968. Ecological studies on the jelly-fish, Aurelia aurita, in Urazoko Bay, Fukui PrefectureII. Occurrence pattern of the ephyra. Bull. Jap. Soc. Sci. Fish., vol. 34, no. 11, pp. 33-39 (in Japanese).

1969a. On the occurrence of the jelly-fish ephyra in Niyuura Bay, Fukui Pref. The Aquiculture. vol. 17, no. 1, pp. 33-39 (in Japanese).

-1969b. Ecological studies on the jelly-fish, Aurelia aurita in Urazoko Bay, Fukui PrefectureIII. Growth. ibid,, vol. 17, no. 2, pp. 145-154 (in Japanese).

1971. Ditto-IV. Monthly change in the bell-length composition and breeding season. Bull. Jap. Soc. Sci. Fish., vol. 37, no. 5, pp. 364-370 (in Japanese).

* Referred to indirectly. 